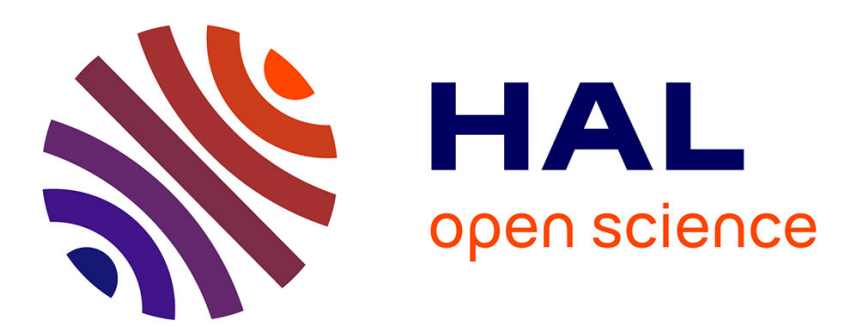

\title{
Progress in understanding processes underlying occupational accidents on the level based on case studies.
}

\author{
Sylvie Leclercq, S. Thouy, E. Rossignol
}

\section{To cite this version:}

Sylvie Leclercq, S. Thouy, E. Rossignol. Progress in understanding processes underlying occupational accidents on the level based on case studies.. Ergonomics, 2007, 50 (1), pp.59-79. 10.1080/00140130600980862 . hal-01618321

\section{HAL Id: hal-01618321 \\ https://hal.science/hal-01618321}

Submitted on 17 Oct 2017

HAL is a multi-disciplinary open access archive for the deposit and dissemination of scientific research documents, whether they are published or not. The documents may come from teaching and research institutions in France or abroad, or from public or private research centers.
L'archive ouverte pluridisciplinaire HAL, est destinée au dépôt et à la diffusion de documents scientifiques de niveau recherche, publiés ou non, émanant des établissements d'enseignement et de recherche français ou étrangers, des laboratoires publics ou privés. 


\title{
Progress in understanding processes of underlying occupational accidents on the level based on case studies
}

\author{
S. LECLERCQ*, S. THOUY and E. ROSSIGNOL \\ French National Research and Safety Institute (INRS) \\ Working Life Department - Biomechanics and Ergonomics Laboratory \\ 54501 Vandoeuvre, France
}

\begin{abstract}
The purpose of this work was to further our knowledge of contexts surrounding accidents on the level in occupational situations with a view to proposing suitable actions for the prevention of these accidents. The study, undertaken at three establishments belonging to a national rail transport company, was based on quantitative and qualitative analysis of accident-onthe-level data available at the establishments concerned, typology of these accidents, interviews with victims and activity analysis. Understanding accidents on the level through building scenarios makes it possible to consider the relevance of prevention actions such as workplace or environmental design/remediation and machine access system design. Moreover, it also makes it possible to consider curtailing the injury-causing aspect of the physical environment by reducing its "aggressiveness". Finally, we discuss the prospects emerging from this work in the research and study field.
\end{abstract}


Keywords: prevention, occupational accident, accident on the level, balance

\section{Introduction}

The frequency and seriousness of accidents on the level in occupational situations are well documented. In France, national health insurance fund CNAM (Caisse Nationale d'Assurance Maladie) has reported the following 2002 statistics for all its insured companies, representing approximately 18 million employees: 168,165 accidents on the level with days lost (22\% of occupational accidents with days lost), of which 9,466 led to permanent disablement. A total of $8,135,691$ days were lost through temporary disablement ( $23 \%$ of days lost through temporary disablement) resulting from accidents on the level and 14 such accidents were fatal (Travail et Sécurité, 2004). Leamon and Murphy (1995) amassed some 91,828 falls on the level (10\% of occupational accidents involving a population of approximately 6 million workers). The average cost of each of these accidents was $\$ 4,363$ and their combined cost represented $13 \%$ of the total cost of all occupational accidents. McNamee et al. (1997) reveal that, since 1990, falls on the level have represented $25 \%$ of all occupational accidents declared in the United Kingdom. The disparity in figures concerning this risk may be explained by the multifactor nature of occupational accidents, which makes it possible to classify them into several different categories (Anderson and Lagerlöf, 1983) and by different definitions or the lack of definition of these accidents (Lortie and Rizzo, 1999; Leclercq, 2005). Moreover, relevant literature employs varied terminology to designate these accidents without always defining them explicitely. The literature focuses on "slips, trips or falls 
on the level" (Health and Safety Executive, 1985), "accidents on the level" (Caisse Nationale d'Assurance Maladie, 1985), "falls" (Leamon and Murphy, 1995), "falls on the level" (Balance et al., 1985), "underfoot accidents", i.e. accidents in which the first unforeseen event is an interaction between the casualty's foot and a support (Manning et al., 1988) or again "slips" (Gronqvist and Roine, 1993). The lack of definition for targeted accidents and the multi-factorial nature of accidents lead to a different possible classification for each of them. For example, accidents occurring on stairs are sometimes classified as "accidents on the level" in some French companies, the "falls from a higher level" category being reserved for high-level falls (e.g. fall from a work cradle or cherry picker). At other companies, accidents occurring on stairs can be listed as "falls from a higher level", especially when there is no risk of falling from a very high level.

The prevention field features relatively few research studies and practical measures despite the importance of the human and financial issue represented by accidents on the level in occupational situations. Leclercq (2005) refers to a number of curbs to preventing these accidents: they are considered minor and commonplace, and are not viewed as "trade/occupation-related accidents", the victim's behaviour is often the only factor questioned, there are no aids specific to controlling this risk and, finally, the risk of an accident on the level is diffuse, i.e. these accidents involve generally only one victim. Their impact is therefore less than that of an infrequent accident involving several victims. In-company awareness therefore represents an essential link in the prevention chain, whose aim must be, in particular, to consider the risk of an accident on the level as an occupational risk in its own right and to prompt analysis of these accidents to ensure their prevention. 
The accident situation on which prevention efforts are currently focused is the slip, when the individual is walking on slippery floors (greasy floors within work premises or floors covered by snow or ice outside premises). Recommended actions (laying of antislip floor covering inside premises or wearing of anti-slip shoes) are designed to prevent a slip or make it more controllable. In this area, research and studies hinge around methodology for measuring slip resistance (Leclercq, 1999a; Courtney et al., 2001). Nevertheless, a foot slipping on a greasy floor, when a person is walking within work premises does not trigger every accident on the level. Evidence is indeed provided by statistical studies based on occupational accidents amassed on databases (Strandberg and Lanshammar, 1981; Strandberg, 1983; Manning et al., 1988; Gronqvist and Roine, 1993; Kemmlert and Lundholm, 1998; Leclercq and Tissot, 2004) or, again, by more clinical studies focusing on in-depth analysis of accidents on the level (Bentley and Haslam, 1998; Leclercq and Thouy, 2004).

Unfortunately, prevention specialists remain powerless in the face of these many other accidents on the level. INRS has conducted a research project in this area; its ultimate aim is prevention of accidents on the level in occupational situations, i.e. prevention of accidents triggered by balance disturbance during work not performed "at height". The project scope includes ground surfaces both without changes of level and with changes of level, such as sidewalk curbs, steps or slopes and the work presented here falls within this scope. It is intended to broaden knowledge of the circumstances surrounding accidents on the level at work based on systemic accident analyses (Leclercq, 2002; 2005). The work situation can effectively be considered as a system with four components: the individual, the task he performs, the equipment he uses and the environment in which he walks (Monteau, 1974). Accident-on-the-level factors 
identified from accident analyses or the literature are linked to all system components (Leclercq, 2002). They reflect disturbances within a component or during interaction between different components. Within the scope of this project, accidents on the level will be characterised as a whole, for example, by a combination of accident factors. Indeed, these accidents are rarely analysed in depth by companies and knowledge concerning them is therefore often limited to "immediate" accident factors involving a component of the physical environment (e.g. an obstruction or slippery floor). Whilst this environmental accident factor is necessary to accident occurrence, it is insufficient on its own. This is why a work situation often reveals isolated accident-on-the-level factors (an obstruction, rapid displacement speed, etc.), which do not contribute to creating an accident. It is a combination of risk factors that causes an accident-causing situation (Monteau, 1997).

With particular consideration for the diversity of accident situations causing accidents on the level (Bentley and Haslam, 1998, 2006; Leclercq and Thouy, 2004), systemic analyses appear unavoidable for achieving the twin objective of identifying work situations likely to cause accidents on the level at a company and understanding what factors, arising at a given moment during the implemented activity in the working environment (in the term's widest possible meaning) and under work situation constraints, prevent the individuals from avoiding disturbance of their physical balance. For the company concerned, these analyses thus allow prevention field priorities to be derived and knowledge of contexts in which these accidents occur to be amassed within a perspective of generalising certain results. 


\section{Method}

The approach implemented in this study conducted at three establishments is globally the same as that adopted by the same authors at another company (Leclercq and Thouy, 2004).

\subsection{Brief description of establishments}

This study was conducted in 3 out of 300 establishments belonging to a national rail transport company. Each of these 3 establishments fulfils different missions and employs different trade/occupations.

- Establishment A groups together 913 employees, including 486 working in the commercial development sector (selling of rail tickets, passenger reception and safety) and 352 working in the production and transport sector (train marshalling manoeuvres, operating points, etc.). 76 employees work in other sectors within the establishment.

- Establishment B groups together 1057 employees around 4 activity sectors: the train drivers sector employing 653 train drivers, the logistics sector with 60 employees working on maintenance, certain engine breakdowns and engine movements, the engine maintenance sector with 150 employees and a sector employing office workers and cleaning staff .

- Establishment C grouped together 602 employees in 1999 and 2000, and 717 employees in 2001 and 2002. These employees check tickets and ensure certain services on trains as well as passenger safety. 279 employees who work in main 
line services, 167 in inner suburban line services and 156 in 1999 and 2000, or 271 in 2001 and 2002, in home station-based regional line services.

\subsection{Analysis of accident-on-the-level information available at the company}

2.2.1 Description of initial injury data. Every occupational accident, whether it led to days lost or not, is recorded by the company and is associated with a number of variables, some of which are systematically, and others infrequently, included in the accident record. These data are:

- the accident date and time,

- the victim's identity and age,

- the accident geographical site and location,

- the accident class (accident on the level, handling accident, road accident, etc.),

- the type of work performed and the victim's activity at the time of the accident,

- the tools and personal protective equipment used,

- the climatic and environmental conditions,

- the chronology of events leading to the accident,

- the accident consequences (injury and number of days lost).

Most accidents on the level covered by the definition provided in the introduction to this paper are listed in the "accident on the level" or the "falls from a higher level" categories. In this company, no occupational accident caused a fall from a great height. Our study therefore focused on these two occupational accident categories, to which we will refer to as "accidents on the level" in the remainder of this document. Most of the 
commuting accidents are categorized as "accidents on the level". They might have different causes and consequences to accidents on the level that occur at work sites. However, if all accidents on the level that occur at work sites in a multi-trade company are considered, these do not have the same causes and consequences either. In this study, accidents on the level occurring at work sites and commuting accidents are considered together because company was concerned with preventing accidents on the level as a whole. Commuting accidents represented less than $10 \%$ of accidents taken into account. Moreover, within the scope of in-depth accidents analyses, potential specific characteristics of commuting accidents will be disclosed. Investigations were held at the three establishments in 2002 and 2003. At each establishment, available information on accidents on the level with and without days lost, which had occurred during the four years preceding the investigation, was analysed. Although a more sizeable volume of data would have been available, earlier information was not used for two reasons: firstly, for fear of distancing ourselves from current reality (constantly changing work situations) and secondly, in order to be able to acquire the maximum amount of information concerning the victims' past accidents. As far as prevention is concerned, accidents on the level with and without days lost have been taken into account, except for the quantitative analyses as explained in the next paragraph.

[Insert table 1 about here]

2.2.2. Quantitative analysis. For each establishment, the relative proportions were first calculated, represented by accidents on the level and days lost because of these 
accidents amongst all occupational accidents and corresponding days lost. A frequency index was also calculated for accidents on the level with days lost.

Frequency indices were then calculated within each establishment according to age and trade/occupation, to observe whether some populations are more affected than others by these accidents. Indeed, unlike many categories of occupational accidents, every person is effectively exposed to the risk of an accident on the level. However, previous research has shown that populations could be more or less affected, depending on their age or trade/occupation (Buck and Coleman, 1985; Kemmlert and Lundholm, 1998; Gauchard et al., 2001; Leclercq and Thouy, 2004). The frequency index was calculated using the following formula:

Frequency index $=$ (number of accidents on the level in the population concerned during $\mathrm{N}$ years $\left.\mathrm{x} 10^{3}\right) /($ number of persons in population concerned $\mathrm{x}$ N)

Only accidents on the level with days lost were used for calculating frequency indices because it was assumed that accidents on the level without days lost could be less systematically declared and that, in this case, the number of accidents listed might be less representative of the real number. In establishments $\mathrm{A}$ and $\mathrm{B}$, there were few personnel movements during the 4 years considered and the age- and trade/occupationbased population distributions, taken into account for calculating these indices, are those corresponding to the years 2001 and 2003 respectively. Regarding establishment C, 120 employees joining at the start of 2001 led to calculating these frequency indices firstly for years 1999 and 2000 and secondly for years 2001 and 2002. Age- and 
trade/occupation-based population distributions taken into account for calculating frequency indices are those for years 2000 and 2002 respectively. Frequency index values were statistically compared using a proportional comparison test. The difference between values was tested at a confidence level greater than $90 \%$. Real confidence levels (greater than 90\%) will be referred to and not the threshold value considered for the test $(90 \%)$.

When information was available concerning the time periods that had passed between accident occurrence and the last rest day and between accident occurrence and starting work, the number of accidents with days lost were represented according to these time periods.

2.2.3. Search for recurrent accident scenarios. Accidents on the level occur in varying circumstances and this is why recurrent accident scenarios and the resulting average number of days lost at each establishment were sought. For this, accident typology was first established based on the victim's activity at the time of the accident and the accident location. This information is very often recorded and represents two essential components of the work situation (Monteau, 1974). Only some of the accidents amassed could be used for this typology, which provided several accidentcausing situations (cf. table 1). For the others, there was no victim activity at the time of the accident and/or accident location. Secondly, analysis of some accident-causing situations were further clarified by interviewing victims to build up the logical chain of events leading to injury. This latter process was performed using the causal tree method (Monteau, 1997). This method allows phenomena generated by the work situation and contributing to the accident to be sought. This search starts from the injury itself (the 
first known event) and works its way back systematically, step by step, asking the following questions for each known event: "What event was required for it to appear?" - "Was another event required?", until a "no" answer is given. Questioning enables events to be interlinked. Examples of causal trees have been given within the context of a previous study (Leclercq and Thouy, 2004). For each situation considered, the number of accidents on the level and the number of victims interviewed by an ergonomist are given in Section 3.2. The time from the injury was variable but less than 4 years, the period considered for the study. The three establishments combine more than seven trades. For each one, the work activity was observed and work activity-related verbal information was obtained from operatives to enhance the understanding of the presence and role of certain accident factors and to highlight accident on the level potential factors. Observations and work activity-related verbal information were guided by hypotheses derived from previous analyses (quantitative analysis, causal trees). The frequency or type of movement and the premises or environment, in which movements occurred and which provide a potential link with accidents on the level, will be evoked through accident scenarios. Based on the knowledge from causal trees and data relating to employee activity, an accident scenario was built up for each accident-causing situation. This scenario consolidates elements of understanding in relation to various accidents on the level and will form a basis for discussion around possible prevention paths. The numerous accident-causing situations meant that only some of them could be analysed in depth. The chosen situations were the most frequent or serious (according to the number of days lost) accident-causing situations. 


\section{Results}

\subsection{Quantitative analysis}

For each establishment, table 1 shows the number of accidents on the level during the 4 years, the workdays lost as a result of these accidents, the relative proportion of accidents on the level and days lost due to these accidents in relation to all occupational accidents and days lost, along with a frequency index for accidents on the level with days lost. This table confirms that accidents on the level represent effectively a large proportion of occupational accidents with days lost and that their seriousness at establishments A and B, evaluated from the proportion of days lost, is greater than the average seriousness of accidents with days lost. It also shows that employees at establishment $\mathrm{C}$ sustained nearly three times the number of accidents on the level with days lost as establishment A and B employees.

[Insert table 1 about here]

For each establishment, again, figures 1 and 2 represent the frequency index for accidents on the level with days lost according to the victim's age and trade/occupation respectively. These figures show that, depending on their age, employees were not equally affected by accidents on the level with days lost. This was observed at all three establishments.

Figure 1 shows that, at establishment A, employees aged between 18 and 24 years and those aged between 45 and 54 years sustained more accidents on the level with days lost 
than employees aged between 25 and 34 years. The difference of the order of $10 \%$ is significant at a confidence level exceeding 95\%. At establishments B and C, the youngest employees were most affected by accidents on the level with days lost: at establishment B, a difference of approximately $15 \%$ between employees in the $18-25$ age bracket and other employees was calculated. The frequency indices are different at a confidence level exceeding 93\%. At establishment C, a difference of between $40 \%$ o and $80 \%$, depending on the age bracket and years considered, between employees in the 18 - 35 age bracket and other employees was calculated. The frequency indexes are different at a confidence level exceeding $95 \%$.

Figure 2 reveals that, at establishment A, production-transport sector employees sustained more accidents on the level with days lost. The difference is of the order of $7 \%$, which is statistically significant at a confidence level exceeding $90 \%$. At establishment B, the logistics and engine maintenance sectors were more affected than the train drivers sector or the office workers and cleaning staff sector. Differences between frequency indices, of the order of $10 \%$, are significant at a confidence level exceeding 90\%, except between the train drivers and logistics sectors for which the difference is not significant. At establishment $\mathrm{C}$, guards/inspectors on home station based regional trains sustained more accidents on the level with days lost. In years 1999 and 2000, the differences between the frequency index for this unit and those for the other two units were $13 \%$ and $30 \%$ respectively. These differences are significant at a confidence level exceeding 95\%. In years 2001 and 2002, only the $28 \%$ difference between the frequency index for this unit and that for main lines is significant at a confidence level exceeding $95 \%$. 
[Insert figures 1 and 2 about here]

For establishments $\mathrm{B}$ and $\mathrm{C}$, figure 3 represents the number of accidents on the level that occurred in relation to the number of days that passed between accident occurrence and the last rest day. For establishment B, figure 4 represents the number of accidents on the level that occurred in relation to the number of hours that passed since starting work. Only these graphs could be drawn up from the available data. They highlight greater occurrence of accidents on the level on days following a rest day and during the first hours after starting work.

[Insert figures 3 and 4 about here]

\subsection{Search for recurrent accident-on-the-level scenarios}

For each establishment, table 2 displays an accident-on-the-level typology based on the victim's activity at the time of the accident and the accident location as well as the average number of days lost for each type of accident on the level. This table shows the wide diversity of accident-on-the-level contexts, not only within several establishments, but also within a single establishment. Accident-causing situations, displayed in bold print in table 3, were analysed in depth because of the large number of resulting days lost or their frequency. These analyses were based on summarised information concerning these accidents complemented by information provided by interviews with the victims concerning a limited number of accidents as well as activity analysis. This 
made it possible to propose an accident scenario for each situation; these scenarios are described below.

\section{[Insert table 2 about here]}

In the case of establishment $\mathrm{C}$, combined analysis of employee activity and accidents led us to modify accident typology, grouping together accidents sustained by employees inspecting home station-based regional trains. These accidents would in fact be closely linked to the type of train considered. Amongst the 69 accidents included in this typology, employees from this unit sustained 27. 15 accident reports stated that these accidents occurred just before train departure (6 accidents when carriage doors were closing, 7 when climbing up into the train and 2 when walking on the platform) and 5 accidents resulted from slipping on a running board.

The employee is on the platform, supervising passenger movement just before departure of this type of train. He whistles to warn them that the train is going to leave and that they should stop climbing aboard. He climbs onto the train and activates the system closing all the carriage doors except for the door to the compartment, in which he himself is standing. The train moves away and the employee watches the passengers remaining on the passing platform. He remains ready for anything (a passenger jumping on after train departure) and he can stop the train at any time. As soon as the train has gathered speed, the employee closes his own door.

The access system for these trains, shown in figure 5, conditions the employee's activity. The central vertical bar (excluded from some carriages) and the running board outside the doors make it possible for passengers to climb on to the running board and 
hold on to the vertical bar after train departure. Moreover, the doors do not always close fully and they can sometimes be reopened. This is why it happens that passengers try to force an entry at the last moment, even when the train is already moving. The guard's/inspector's attention is therefore focused "for a long time" on movement of passengers to ensure their safety. Furthermore, the running board is exposed to climatic conditions and its construction does not allow drainage of water, which can freeze in winter and may be a cause of slipping. On other trains, the running board can be protected by the carriage doors or be retractable. Finally, the carriage door opening and closing system shown in figure 5 is subject to malfunctions. Accident reports state that the guard's/inspector's door in fact closes when he has actuated closure of all doors except his own. Observations have revealed that, in some cases, the employee places his foot against the door to prevent it from closing in front of him. The potential impact of the access system on the occurrence of accidents on the level could explain the fact that the guards/inspectors working on these trains sustained the greatest number of accidents on the level.

[Insert figure 5 about here]

Scenario 1 - Establishment A - Accidents occurring when walking on a flat surface (7 accidents -5 interviews). A person walks at normal speed at his normal workplace or on his/her usual way to/from work. The ground surface has become temporarily slippery (due to climatic conditions or presence of wet cleaning product). Caught unawares by the unexpected slipperiness of the floor, the victim's foot slips uncontrollably on the 
floor (accelerated slip over an excessive distance). The person's balance is disturbed and he/she falls.

Comments. In 5 cases out of 7 , the accident occurred around the time at which the victim started work (between 30 minutes before and 2 hours after). Collected information offers no explanation and victims are not generally subjected to a time constraint. It may be possible to explain the fact that these accidents were more frequent around at which victims started work as follows: between home and workplace, people are often confronted by variations in the state of the ground surface on which they walk, i.e. damp pavements, ice sheets, etc. The risk of being caught unawares by a slippery ground surface or an obstruction is therefore higher.

Scenario 2 - Establishment A - Accidents occurring when walking on a surface featuring a small obstruction (12 accidents -6 interviews). A person walks at normal speed in a familiar place, which is not his/her usual workplace. The ground surface features a small obstruction that the victim does not see because he/she is looking elsewhere (another person to whom he/she is talking, the car to which he/she is walking, etc.). The victim trips, but recovers his/her balance.

Comments. At least three accidents occurred in a corridor, in which there was a single step ( 2 cases) or a different step (non-uniform step height, which decreases over its whole width -1 case)

Scenario 3 - Establishment A - Accidents occurring when going up or down stairs (16 accidents - 5 interviews). A person at his/her usual workplace or on his/her normal way to/from work goes down stairs often at high speed (to avoid the rain or to save 
time, when on the move; time he/she wants to devote to other tasks). The stairs are in bad condition or are slippery. The person's foot slips on a step. The slip is neither long not necessarily accelerated, but the victim, whose foot slides into space, falls.

Comments. These accidents are similar to scenario 1 slips in terms of familiarity with location, the fact that the person was on the move without pursuing any other physical activity and the accident (fall) consequences. They differ due to a probably less critical degree of slipperiness, but the risk of falling is greater in scenario 3, not only because of the small step area and the descending activity, but also because persons were sometimes moving fast.

Scenario 4 - Establishment B - Accidents occurring when climbing up onto or down from engine running boards (44 accidents - 6 interviews). The employee climbs down, whilst facing the engine. He is not in any particular hurry and he is familiar with both the work location and situation. The running board steps are one above the other like ladder rungs. They are flush with, or project only little from, the engine. The distance between steps often varies and the height of the step nearest the ground depends on the location at which the engine is stopped. If this is alongside a platform, the height of the bottom step will be reduced by the height of the platform above ground. If this is alongside the space between lines or a track, the height of the bottom step will be greater. It can be of the order of 60 centimetres. The handrails held by the employee, when climbing up or down are approximately 120 centimetres from the ground. This height is again variable depending on the type of engine. The employee cannot see where he places his foot. His three of four climbing holds (both hands, one or two feet) are almost in a vertical plane. His two feet are close together on steps, whose depth is 
sometimes of the order of only 15 centimetres. His balance is somewhat unsteady and the higher the bottom step and handrails, he more has to pull up with his arms, when climbing up, and to falling down by supporting part of his weight with his arms. When the bottom step is high, he lets his hands slide over the handrails when climbing down and releases them as soon as his foot touches the ground. The higher the bottom step, the greater impact on his foot, when it touches the ground. Thus, on uneven ground (e.g. coarse ballast), the higher the step and the more uneven the ground, the greater the likelihood of an ankle injury. This is what happens in some accident cases. In others, the employee feels shoulder pain at the instant his foot touches the ground. In this case, it would seem likely that the forces in his arms, when climbing up onto or down from the engine, have contributed to this injury.

Comments. Employees complain of handrail slipperiness. They exert regularly forces on their arms to lift or restrain their bodies, when climbing up or down respectively. Handrail slipperiness therefore inhibits them on occasion, whilst at other times they let their hands slide over the handrails to complete their descent from high bottom steps.

Scenario 5 - Establishment B - Accidents occurring when walking on lines or tracks (21 accidents - 9 interviews). Train drivers sustained four accidents, which shared common features and occurred during inspection prior to train departure. Following these analyses, we therefore propose two scenarios, of which the more detailed (scenario 5b) corresponds to these four accidents.

Scenario 5a. The situation is of an emergency nature. The employee walks hurriedly on the line or track. He does not see the obstruction, often because he could not see it 
(concealed obstruction, night-time, attention focused on other situation elements). He trips or twists his ankle; he falls in one case out of three.

Scenario 5b. The employee performs an inspection prior to train departure. The situation is unusual (e.g. emergency stop, problem detected during inspection); the employee is worried, even panicking (case of one 25 year-old employee with less than 3 years experience, confronted by a breakdown he has never encountered). He is worried about delaying train departure and he walks hurriedly along the train or on the line. He does not see the obstruction on, or unevenness in, the ground. He trips or twists his ankle; he falls in one case out of two, sometimes onto the engine.

Scenario 6-Establishment $C$. Accidents sustained by employees on a train type with an access system shown in figure 5 (27 accidents - 4 interviews).

Scenario $6 a$ (3 accidents). After whistling train departure, the employee walks on the platform to climb aboard the train. His attention is focused on movement of passengers, whose safety he must ensure. He trips in a hole or on a difference in level on the platform or he misses the step, when trying to climb onto the train.

Scenario $6 b$ (1 accident). The employee slips on the running board, when climbing down from the train in the rain.

Comments. Employees in this unit are often required to initiate train departure (train stopping every 4 minutes on some lines) and are often exposed to these accidents. Most recruits start in this unit, which is characterised by its young personnel. 
With regard to the second category of accidents occurring when climbing up onto, or down from, running boards, employees working on inner suburban trains sustain these more frequently (15 victims out of 22). They occur more often when climbing onto the train (14 cases) than when climbing down from the train (8 cases). The above paragraphs concerning the work situations of employees working on home station-based regional trains provide data for understanding these results.

Scenario 7 - Establishment C. Accidents occurring when climbing onto or down from train running boards (7 accidents - 22 less 15 considered in previous scenarios - 3 interviews). Only one accident out of three is triggered by balance disturbance: the employee climbing onto the train at a place where the track is curved. He held onto the left handrail with his left hand and held his two bags one above the other with his right hand. He missed the step (unusual gap between platform and running board) and his trunk slipping down between the platform and the train.

Comments. In this accident case, we may ponder the part played by carrying bags in accentuating balance disturbance. Moreover, this accident reveals a seriousness factor (contributing to injury aggravation): the gap between the platform and the train. Amongst the 22 accidents that occurred when climbing onto or down from a train, 6 accident reports refer to the employee's leg or trunk slipping down between the platform and the train. Height and gap between platform and train are in fact highly variable depending on the station and even at the same station and there may be differences in level on the platform or curved rail tracks. 
The other two interviews concerning accidents occurring when climbing onto, or down from, running boards were not triggered by balance disturbance: the employee, carrying his bags with work equipment, felt a pain in his back or hip, when he climbed onto, or down from, a stationary train.

Scenario 8 - Establishment C. Accidents occurring when walking down a moving train (14 accidents - 4 interviews). When walking down a moving train, an employee's balance is disturbed by a sudden movement of the train and/or he trips on an item of luggage. In both cases, injuries result from the fact that the individual collides with his immediate environment.

Comments. In both cases, the employee's balance was disturbed due to luggage in the central corridor. Passengers leave their luggage here notably because luggage racks are full. In some carriages, steel bars have been installed under seats to prevent bags being placed or trapped there. So, some bags are left in the central corridor. In other cases, passengers want to keep their luggage near them for fear of theft. A lone guard/inspector does not always dare have the corridor cleared by passengers.

The employee who lost his balance collided with his immediate environment in two accidents. In the first case, this involved a bench seat in a carriage, in which these were not in line, obliging the guard/inspector to move "obliquely" in the central corridor and resulting in impacts to the legs, when the employee's balance is unexpectedly disturbed. In the second case, the accident involved a luggage rack. The employee standing in front of the guard's/inspector's compartment had his balance disturbed by a sudden movement of the train. He collides with the luggage rack in front of the guard's/inspector's compartment. This luggage rack was originally fitted with metal 
parts that could be raised to allow stowage of bulky bags. These parts were missing and the remaining structure featured projecting corners at head and lower back levels.

\section{Discussion}

In-depth analyses of accidents on the level conducted by INRS (Leclercq and Tissot, 2004; Tissot and Leclercq, 2005; Leclercq and Thouy, 2004) have permitted a clear definition of accidents to be prevented. The term "accident on the level" has been substituted for the more restricting term "fall on the level" because many occupational accidents triggered by balance disturbance have not resulting in the victim falling (Leclercq and Thouy, 2004). As examples, we can also refer to scenarios 4 and 5 of this study (cf. § 3.2.), which describe cases in which the victim did not fall, yet a sprain resulted from disturbance of his/her balance.

This study confirms both the necessity and the insufficiency of an approach exclusively centred on preventing a slipping event. Work carried out to prevent slipping is essential because it provides a specific response to one category of accidents on the level, resulting most often in a fall. Accidents on the level triggered by the foot slipping on the ground (cf. scenarios 1 and 3) are effectively the only ones to have systematically caused the victim to fall. On the other hand, this research remains insufficient because other events may trigger accidents on the level: a trip (scenario 2), brutal impact of the foot on uneven ground (scenario 4), acceleration or deceleration of a means of transport (scenario 8). The authors therefore consider that notion of balance disturbance corresponds better to the triggering event with respect to these accidents. Finally, only consideration of the accident in relation to its dynamics, i.e. upstream of the 
triggering event, allows us to foresee with greater breadth actions in the prevention field. Understanding of accidents on the level provided by building scenarios enables us to study the suitability of the following prevention actions: design/alteration of rooms/environments (scenarios 2 and 7), design of engine access systems (scenarios 4 and 6). These scenarios also allow us to envisage reducing the injury-causing aspect of the environment (scenarios 7 and 8). It should indeed be remembered that injury seriousness could be curtailed, in particular, by reducing the "aggressiveness" of the immediate physical environment (Leclercq, 2005).

Frequency indices calculated in relation to age or trade/occupation exercised by the victim show that individuals were not equally affected by accidents on the level. These results back up the hypothesis according to which factors governing these accidents should be sought, in particular, in work situation characteristics (experience, activity constraints, equipment used, etc.).

At two establishments out of the three examined in the present study, the youngest employees were also affected more than others by accidents on the level with days lost. At establishment $\mathrm{C}$, the difference amounts to $80 \%$ o depending on the ages considered. In this establishment, junior employees (in general the youngest) start their career by working on home station-based regional trains. Observations have led to questioning equipment characteristics in relation to accidents on the level. These characteristics indeed condition employee activity (see Figure 5 and Scenario 6).

The observation according to which young employees were more affected by accidents on the level at most of the studied establishments and in a previous study on accidents on the level in a multi-trade company (Leclercq and Thouy, 2004) cannot be generalised. Based on national statistical data provided by the Health and Safety 
Executive (HSE), Buck and Coleman (1985) have shown that the frequency level of "slips, trips and falls on the level" occurring in occupational situations increases with employee age (between 16 and 60 years). Kemmlert and Lundholm (1998) have observed from analysis of 1600 "slips, trips and falls" at work that persons older than 45 years sustain more of these accidents than younger persons. On the other hand, Bentley and Haslam (1998) have observed no significant age effect on the occurrence of falls amongst postmen. The results of the present study reveal that reasons which could explain the higher aged-related frequency of accidents on the level in occupational situations should be sought elsewhere than in the susceptibility to falls of elderly persons; a susceptibility that is indeed apparent in the non-working population older than approximately 70 years (Pyykö et al., 1990; Alexander et al., 1992; Perrin and Lestienne, 1994). Laflamme and Menckel (1995) have analysed the relation between age and occupational accidents based on literature published in the 30 years preceding their study, with the aim of understanding the contradictory results reported therein. The authors observe that large scale studies, which assume that work-related risk factors are identical for all age groups (highly questionable), can give results in conflict with studies conducted at a more refined level, often within a specific activity sector. Greater age usually leads to a reduction in physical and mental capacities, but it also prompts more efficient use of resources due to experience. Moreover, as age increases, injuries are more serious and recovery slower in the event of an accident. The age/accident relationship is subject to many factors, which cannot be taken into account in studies of a statistical nature. Laflamme and Menckel (1995) refer to the difference in risk exposure according to age group as a factor that could explain the differences in agerelated accident occurrence. These results point out that even within the same 
trade/occupation (train guard/ticket inspector), employee exposure varies effectively according to the type of carriage and, in particular, the access system equipping the carriages in which these employees work. A study of the impact of living experience under a winter climate, including snow and ice, on slip occurrence, conducted by Gao and Abeysekera (2004), stresses the difficulty in distinguishing the age factor from the experience factor. Cellier et al. (1995) studied the effects of age, work experience and their interaction on accident occurrence at several food sector companies. This work revealed the need to identify, as closely as possible, work situation constraints and personal characteristics both in terms of age and experience, when studying the impact of these different factors on the occurrence of accidents, in particular, accidents on the level. The authors also conclude that mechanisms operating in accident occurrence can be identified through clinical analyses of these same accidents. This type of analysis conducted within the scope of the present study makes it possible effectively to explain a number of unexpected results based on more detailed knowledge of the work situations concerned. For example, we observed that accidents on the level sustained by train guards/inspectors when climbing onto or down from running boards most frequently occur when entering a train than when leaving a train. This result is unexpected in the sense that literature concerning accidents occurring when going up or down stairs reports a higher accident frequency when descending (Cohen et al., 1985; Nagata, 1991; Jackson and Cohen, 1995) and that the stair descending activity is more dangerous, in particular because of the acceleration due to gravity and height of a fall in the event of balance disturbance (Templer, 1992; Roys, 2001). In the particular situation involving guards/inspectors working on the type of carriage shown in figure 5, activity analysis revealing that the employee's visual attention is focused on passenger 
movement, when he climbs onto the train, makes it possible to understand the frequency of accidents on the level that occur when climbing onto running boards. It should be stressed that, amongst sensorial information contributing to balance adjustment, visual data is the only information that allows the risk of balance disturbance to be anticipated before entering a risk zone (obstruction, slippery floor, etc.). Vestibular and proprioreceptive information reflect balance disturbance only when it occurs (Patla, 1997; Leclercq, 1999c). Accident-on-the-level scenario 6, referred to above, also reminds us that visual data is information that is shared between the task to be performed and the implicit task of maintaining physical balance and that, in some situations, this information can be lacking in relation to maintaining balance. In the scenario 2 case, the individual overlooks the obstruction because it is unexpected (a step in the corridor) and, moreover, the individual doesn't find himself in his usual workplace. It would seem that he does not focus his attention of the environment because he assumes that the corridor within the premises is a flat walking surface. Certain aberrations therefore appear when designing or altering the premises because of concerns for easiness, cost saving or aesthetics. The implicit argument that prevails in these situations is that a step is visible and can thus be anticipated. It is forgetten that the individual cannot always see the step and that he often makes assumptions in an unfamiliar environment; for example, he assumes that "a walking surface in a corridor is flat".

Accidents on the level sustained by train drivers when climbing down from running boards (scenario 4) are totally different to accidents on the level sustained by train guards/inspectors, when climbing up onto or down from running boards (scenarios 6a 
and 7). In the prevention field, paths to progress emerging from an understanding of accident processes differ according to situations.

The results also indicate that accidents on the level occurred most frequently on days following a rest day and during the first hours at work. This observation, recurrent at several establishments and already expressed in a previous study (Leclercq and Thouy, 2004), deserves more systematic investigation and analysis. The literature dealing with accidents on the level provides no hint of an explanation to these results. In relation to occupational accidents in general, Davezies (2002) explains the higher frequency of occupational accidents on Monday by the change in rhythm, which imposes on an individual a higher burden than that sustained under steady operation.

The present study involved three establishments and a diversity of processing operations: quantitative and qualitative analysis of data on past accidents on the level; accident on the level typology; interviews; activity analysis. This processing diversity was made necessary by the desire to consider the heterogeneous combination of accidents on the level, which occurred in work situations that were themselves different. The analyses are descriptive (especially the quantitative data processing) and some of them could not be carried out in depth, in particular with regard to activity analysis because detailed analysis of multiple tasks is unfeasible in this study. In the authors' view, the major limit affecting the whole of this work resides in the empirical nature of the adopted approach. For example, accidents on the level were classified in this study based on the activity at the time of the accident and the accident location. It should be emphasized that, within the same trade/occupation (train guard/ticket inspector), an additional criterion determining the guard's/inspector's activity turned out to be essential to characterising accidents on the level. This third criterion was the type of carriage, on 
which the guards/inspectors worked. Enhanced knowledge and concepts concerning these accidents and their prevention should lead to optimisation of their necessary classification and more generally to approaches that could be less empirical.

\section{Conclusion}

In 2004, Leclercq and Thouy highlighted the diversity of circumstances surrounding accidents on the level within a multi-trade company, the diversity of accident factors and the recurrent nature of certain accident-on-the-level scenarios. The study presented here points out a greater diversity of accident-on-the-level contexts within several establishments and, in particular, different contexts within a same trade. This diversity of accident-on-the-level contexts dictates the importance of being able to group accidents together. Although these accidents are widespread in terms of place of occurrence, equipment used and activity developed, some of them present similarities in their progression and can give rise to similar prevention measures. A diagnostic stage prior to devising suitable prevention actions seems to be necessary. Provision of diagnostic data implies possessing sufficient understanding of phenomena. Analyses performed at the company concerned have enabled multiple possible paths to progress in the prevention of accidents on the level to be proposed. Beyond this objective, amassing of results from detailed analyses ensures progress in understanding these accidents by accrediting or invalidating assumptions concerning, for example, the impact of age or experience. Results collected and discussed here plead in favour of a systemic approach of these accidents to get a better understanding of the reasons for their occurrence, which is subjected to numerous accident factors combinations. 
The challenge represented by accident-on-the-level prevention is major at both human and financial levels. Today, research and practice are incompatible with the risk involved. This work reveals a number of risk factors associated with the occurrence of these accidents in occupational situations. It preserves an investigative character, given the small number of studies in the field of these accidents and the diversity of circumstances covered by them. It appears necessary to continue research with the aim of characterising more accurately and exhaustively accident scenarios, for example, and of investigating the degree of generalisation of these scenarios or, again, of explaining the reasons for the unsuitability of personal balance control strategy in these situations. In particular, this study confirmed that in some occupational situations, individuals are unable to cope with a potential balance disturbance because their visual attention is directed to their task at hand and lack of control of balance. From a methodological standpoint, tools and methods for analysing accidents in general have been used. It would also be helpful to make progress in this field, for example by developing a diagnostic approach.

\section{Acknowledgements}

This work was made possible thanks to the cooperation of the French national rail transport company. The authors extend their warmest thanks to this company and, in particular, to its many representatives, without whom this work could not have been performed. The help of company managers involved in safety and that of employees interviewed were especially appreciated. 


\section{References}

AleXAnder, N. B., ShePard, N., GU, M. J. and SchultZ, A., 1992, Postural control in young and elderly adults when stance is perturbed : kinematics. Journal of gerontology : medical sciences, 37(3), pp. M79-87.

ANDERSON, R. and LAGERLÖF, E., 1983, Accident data in the new Swedish information system on occupational injuries. Ergonomics, 26, 33-42.

Ballance, P.E., Morgan, J. and Senior D., 1985, Operational experience with a portable friction testing device in university buildings. Ergonomics, 28(7), pp. 1043-1054.

BENTLEY, T.A. and HASLAM, R.A., 1998, Slip, trip and fall accidents occurring during the delivery of mail. Ergonomics, 41(12), pp. 1859-1872.

BENTLEY, T.A. and HASLAM, R.A., 2006, Epidemiological approaches to investigating the causes of occupational falls. In Understanding and Preventing Fall accidents, R. Haslam and D. Stubbs (Eds), pp. 115-138 (London: Taylor \& Francis).

BUCK, P.C. and COLEMAN, V.P., 1985, Slipping, tripping and falling accidents at work : a national picture. Ergonomics, 28(7), pp. 949-958.

CAisse NATIONAlE D'ASSURANCE MALADIE? 1995? Statistiques Nationales d'Accidents $d u$ Travail (Années 1990 - 1991 - 1992) (Paris: CNAMTS)

Cellier, J.M., Eyrolle, H. and Bertrand, A., 1995, Effects of age and level of work experience on occurrence of accidents. Percept Mot Skills, Jun, 80 (3 pt 1), pp. 931-940.

COHEN, H.H., TEMPLER, J. and ARCHEA, J., 1985, An analysis of occupational stair accident patterns. Journal of Safety Research, 16 (4), pp. 171-181. 
Courtney, T.K., Chang, W.R., GronQvist, R. and RedFERn, M.S., 2001, The measurement of slipperiness - an international scientific symposium. Ergonomics, 44(13), pp. 1097-1102.

DAVEZIES, P., 2002, Mythiques tricheries du lundi. Santé et Travail, 40, pp. 34-34.

GAO, C. and ABEYSEKERA, J., 2004, Slips and falls on ice and snow in relation to experience in winter climate and winter sport. Safety Science, 42, pp. 537-545.

Gauchard, G., Chau, N., Mur, J.M. and Perrin, P., 2001, Falls and working individuals : role of extrinsic and intrinsic factors. Ergonomics, 44(14), pp. 1330-1339.

GRONQVIST, R. and RoINE, J., 1993, Serious occupationnal accidents caused by slipping. In Advances in Industrial Ergonomics and Safety V, R. Nielsen and K. Jorgensen (Ed.), pp. 515-519 (London: Taylor \& Francis, 1993).

Health \& Safety EXecutive, 1985, Watch Your Step, Prevention of Slipping, Tripping and Falling Accidents at Work (London: HMSO)

JACKSON, P.L. and COHEN, H.H., 1995, An In-Depth Investigation of 40 Stairway Accidents and the Stair Safety Literature. Journal of Safety Research, 26(3), pp. 151-159.

Kemmlert, K. and Lundholm, L., 1998, Slips, trips and falls in different work groups with reference to age. Safety Science, 28 (1), pp. 59-75.

LAFlAMME, L. and MENCKEL, E., 1995, Aging and occupational accidents. A review of the literature of the last three decades. Safety Science, 21, pp. 145-161.

LEAMON, T.B. and MURPHY, P.L., 1995, Occupational slips and falls : more than a trivial problem. Ergonomics, 38 (3), pp. 487-498. 
LECLERCQ, S., 1999a, The prevention of slipping accidents: a review and discussion of work related to the methodology of measuring slip resistance. Safety Science, 31, pp. 95-125.

LECLERCQ, S., 1999b, In-company same and low level falls : from an understanding of such accidents to their prevention. International Journal of Industrial Ergonomics, 25, pp. 59-67.

LECLERCQ, S., 2002, Prevention of Falls on the Level in Occupational Situations: A Major Issue, a Risk to be Managed. International Journal of Occupational Safety and Ergonomics, 8(3), pp. 377-385.

LECLERCQ, S., 2005, Prevention of so-called "accidents on the level" in occupational situations : a research project. Safety Science, 43, pp. 359-371

LECLERCQ, S. and THOUY, S., 2004, Systemic analysis of so-called "accidents on the level" in a multi trade company. Ergonomics, 47(12), pp. 1282-1300.

LEClERCQ, S. and TISSOT, C., 2004, Serious falls on the level in occupational situations. In Contemporary Ergonomics, P. T. Mc Cabe (Ed.), pp. 83-87, (London: CRC Press, 2004).

LORTIE, M. and RIZZO, P., 1999, Reporting and classification of loss of balance accidents. Safety Science, 33, pp. 69-85.

McNamee, R., Kemmlert, K., Lundholm, L. and Cherry, N.M., 1997, Injuries after falls at work in the United Kingdom and Sweden with special reference to fractures in women over 45. Occupational and Environmental Medicine, 54, pp. 785-792. 
Manning, D.P., Ayers, I., Jones, C., BruCE, M. and COHEN, K., 1988, The incidence of underfoot accidents during 1985 in a working population of 10000 Merseyside people. Journal of Occupational Accidents, 10, pp. 121-130.

MonTEAU, M., 1974, Essai de classement des risques professionnels et des actions de prévention. Cahiers de Notes Documentaires, 75 (2e trimestre), pp. 255-262.

Monteau, M. 1997, Prise de risque, "dérives" et autres imprudences. Les Notes Scientifiques et techniques de l'INRS, NS 0155, 161p. (Paris : INRS).

NAGATA, H., 1991, Occupational accidents while walking on stairways. Safety Science, 14, pp. 199-211.

PATLA, A.E., 1997, Understanding the roles of vision in the control of human locomotion. Gait and Posture, 5, pp. 54-69.

Perrin, P. et LeStienne, F., 1994, Mécanismes de l'équilibration humaine, 163p. (Paris, Masson).

PYYKKÖ, I. ; JANTTI, P. and AALTO, H., 1990, Postural control in elderly subjects. Age and Ageing, 19, pp. 215-221.

ROYS, M.S., 2001, Serious stair injuries can be prevented by improved stair design. Applied Ergonomics, 32, pp. 135-139.

STRANDBERG, L., 1983, Ergonomics applied to slipping accidents. In Ergonomics of Workstation Design, T.O. Kvalseth (Ed.), pp. 201-228 (London: Butterworths and Co., 1983).

STRANDBERG, L. and LANSHAMMAR, H., 1981, The dynamics of slipping accidents. Journal of Occupational Accidents, 3, pp. 153-162.

TEMPLER, J., 1992, The staircase: Studies of Hazards, Falls and Safer Design. (London: MIT Press). 
TiSsOt, C. and LECLERCQ, S., 2005, Textual analysis of 459 accounts of serious falls on the level in occupational situations. Additional contributions to coded variable analysis. In Contemporary Ergonomics, D. Bust and P. T. Mc Cabe (Ed.), pp. 404-408 (London: Taylor and Francis, 2005).

TrAVAIL et SECURITE, 2004, Statistiques technologiques 2002, travail et sécurité, juillet - août, pp 46-51. 
Table 1: Period and number of accidents considered at each establishment.

Table 2: Relative proportion of accidents on the level and days lost due to these accidents with respect to all occupational accidents and days lost, along with frequency indices for accidents on the level with days lost, for each of the 3 establishments considered.

Table 3: Accident-on-the-level typology based on activity at time of accident and accident location, average number of days lost associated with each type of accident on the level. Average number of days lost excluded for two types of accident on the level because of excessive heterogeneousness of the number of days lost associated with accidents in these classes. 


\begin{tabular}{|c|c|c|c|c|c|}
\hline $\begin{array}{l}\text { Establish- } \\
\text { ment }\end{array}$ & $\begin{array}{l}\text { Period } \\
\text { studied }\end{array}$ & $\begin{array}{l}\text { Number of } \\
\text { accidents on } \\
\text { the level with } \\
\text { days lost } \\
\text { recorded }\end{array}$ & $\begin{array}{l}\text { Number } \\
\text { of days } \\
\text { lost } \\
\text { counted }\end{array}$ & $\begin{array}{l}\text { Number of } \\
\text { accidents on } \\
\text { the level } \\
\text { without days } \\
\text { lost recorded }\end{array}$ & $\begin{array}{l}\text { Number of accidents on } \\
\text { the level considered for } \\
\text { typology development }\end{array}$ \\
\hline A & $\begin{array}{l}1998 \text { to } \\
2001\end{array}$ & 55 & 2372 & 33 & $\begin{array}{c}70 \text { (incl. } 44 \text { accidents with } \\
\text { days lost) }\end{array}$ \\
\hline B & $\begin{array}{l}1999 \text { to } \\
2002\end{array}$ & 70 & 1703 & 44 & $\begin{array}{c}91 \text { (incl. } 61 \text { accidents with } \\
\text { days lost) }\end{array}$ \\
\hline $\mathrm{C}$ & $\begin{array}{l}1999 \text { to } \\
2002\end{array}$ & 109 & 2170 & 28 & $\begin{array}{c}69 \text { (incl. } 50 \text { accidents with } \\
\text { days lost) }\end{array}$ \\
\hline
\end{tabular}




\begin{tabular}{ccccc}
\hline Establishment & $\begin{array}{c}\text { \% of accidents } \\
\text { on the level } \\
\text { out of total } \\
\text { occupational } \\
\text { accidents with } \\
\text { days lost }\end{array}$ & $\begin{array}{c}\text { \% of days lost } \\
\text { due to accidents } \\
\text { on the level out } \\
\text { of total number } \\
\text { of days lost }\end{array}$ & $\begin{array}{c}\% \text { of accidents } \\
\text { on the level out } \\
\text { of total } \\
\text { occupational } \\
\text { accidents } \\
\text { without days lost }\end{array}$ & $\begin{array}{c}\text { Frequency index } \\
\text { for accidents on } \\
\text { the level with } \\
\text { days lost }\end{array}$ \\
\hline A & $40 \%$ & $63 \%$ & $36 \%$ & $15 \%$ o \\
\hline B & $37 \%$ & $60 \%$ & $27 \%$ & $15.6 \%$ o \\
\hline C & $33 \%$ & $30 \%$ & $50 \%$ & $\begin{array}{c}40.7 \% \text { in } 1999- \\
2000 \\
41.8 \% \text { in } 2001- \\
2002\end{array}$ \\
\hline
\end{tabular}




\begin{tabular}{|c|c|c|c|c|}
\hline $\begin{array}{l}\text { Establis } \\
\text { hment }\end{array}$ & Activity at time of accident and accident location & $\begin{array}{l}\text { Number of } \\
\text { accidents }\end{array}$ & $\begin{array}{l}\text { Number of } \\
\text { accidents with } \\
\text { days lost }\end{array}$ & $\begin{array}{c}\text { Average number of days } \\
\text { lost (calculated from all } \\
\text { accidents on the level with } \\
\text { days lost) }\end{array}$ \\
\hline \multirow{5}{*}{ A } & Walking on a flat surface & 7 & 7 & 55 \\
\hline & Walking on a surface featuring a small obstruction & 12 & 11 & 32 \\
\hline & Going up or down stairs & 16 & 9 & 21 \\
\hline & Walking on lines, tracks and planked passages & 16 & 6 & 12 \\
\hline & Climbing up onto and down from engines & 9 & 5 & 10 \\
\hline \multirow{2}{*}{$\mathrm{B}$} & Climbing up onto or down from engine running boards & 44 & 31 & 16 \\
\hline & Walking on lines and tracks & 21 & 13 & 16 \\
\hline \multirow{5}{*}{$\mathrm{C}$} & Walking outside premises & 11 & 8 & 30 \\
\hline & Climbing up onto and down from train running boards & 22 & 17 & 19 \\
\hline & Walking in a moving train & 14 & 8 & 17 \\
\hline & Operating train doors & 10 & 7 & 16 \\
\hline & Going up and down stairs & 12 & 10 & 11 \\
\hline
\end{tabular}


Figure 1: Frequency indexes for accidents on the level with days lost according to victim age, for each of the 3 establishments $\mathrm{A}, \mathrm{B}$ and $\mathrm{C}$. The graph associated with establishment $\mathrm{C}$ takes into account different population distributions according to age for the period studied.

Figure 2: Frequency indices for accidents on the level with days lost according to trade/occupation to which the victim belongs, for each of establishments A, B and C. The graph associated with establishment $\mathrm{C}$ takes into account different population distributions according to trade/occupation for the period studied.

Figure 3: Number of accidents on the level with respect to number of days passed between accident occurrence and last rest day - establishments B and C.

Figure 4: Number of accidents on the level with days lost with respect to number of hours passed since starting work - establishment B.

Figure 5: Access system on home station -based regional trains. 

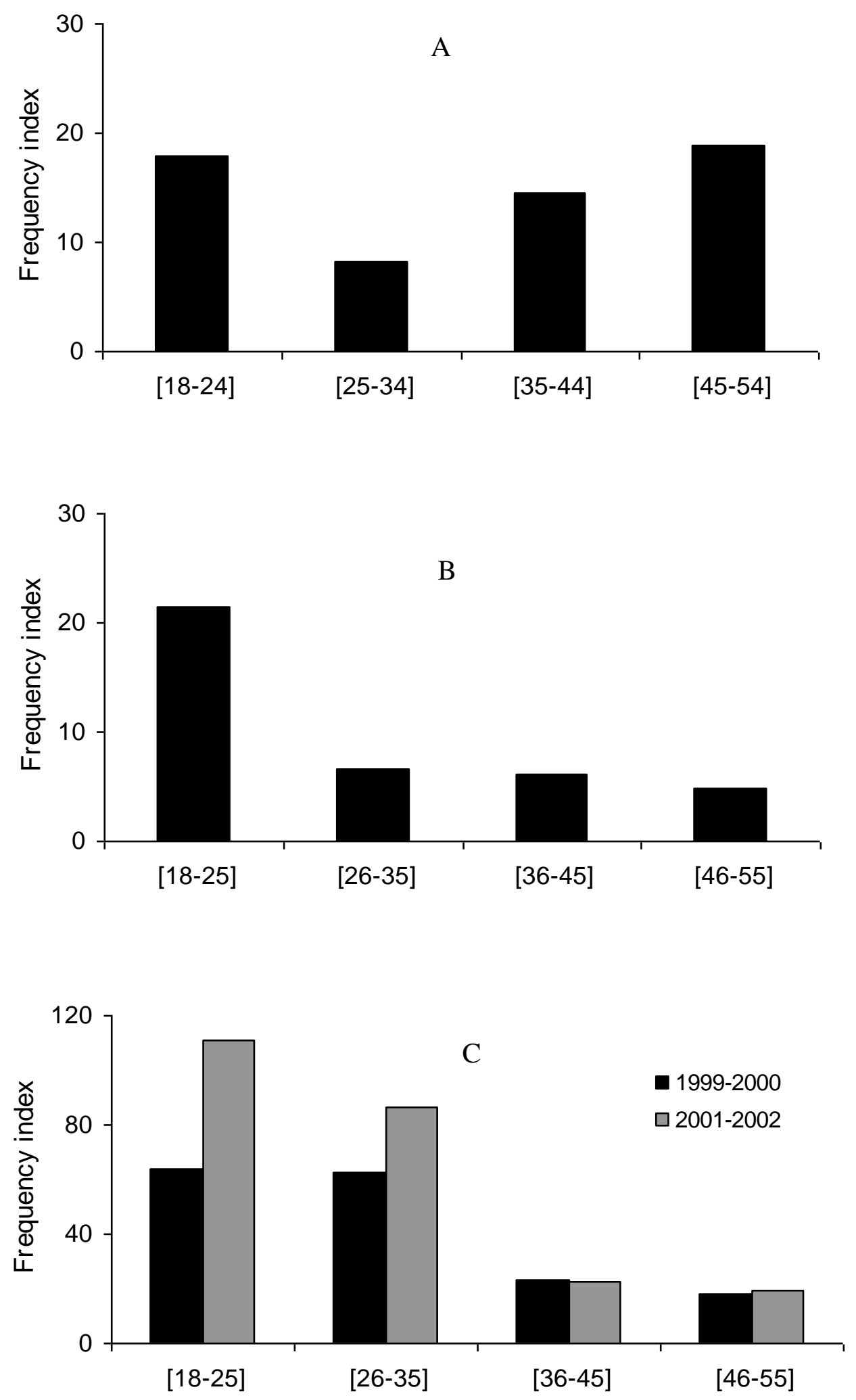

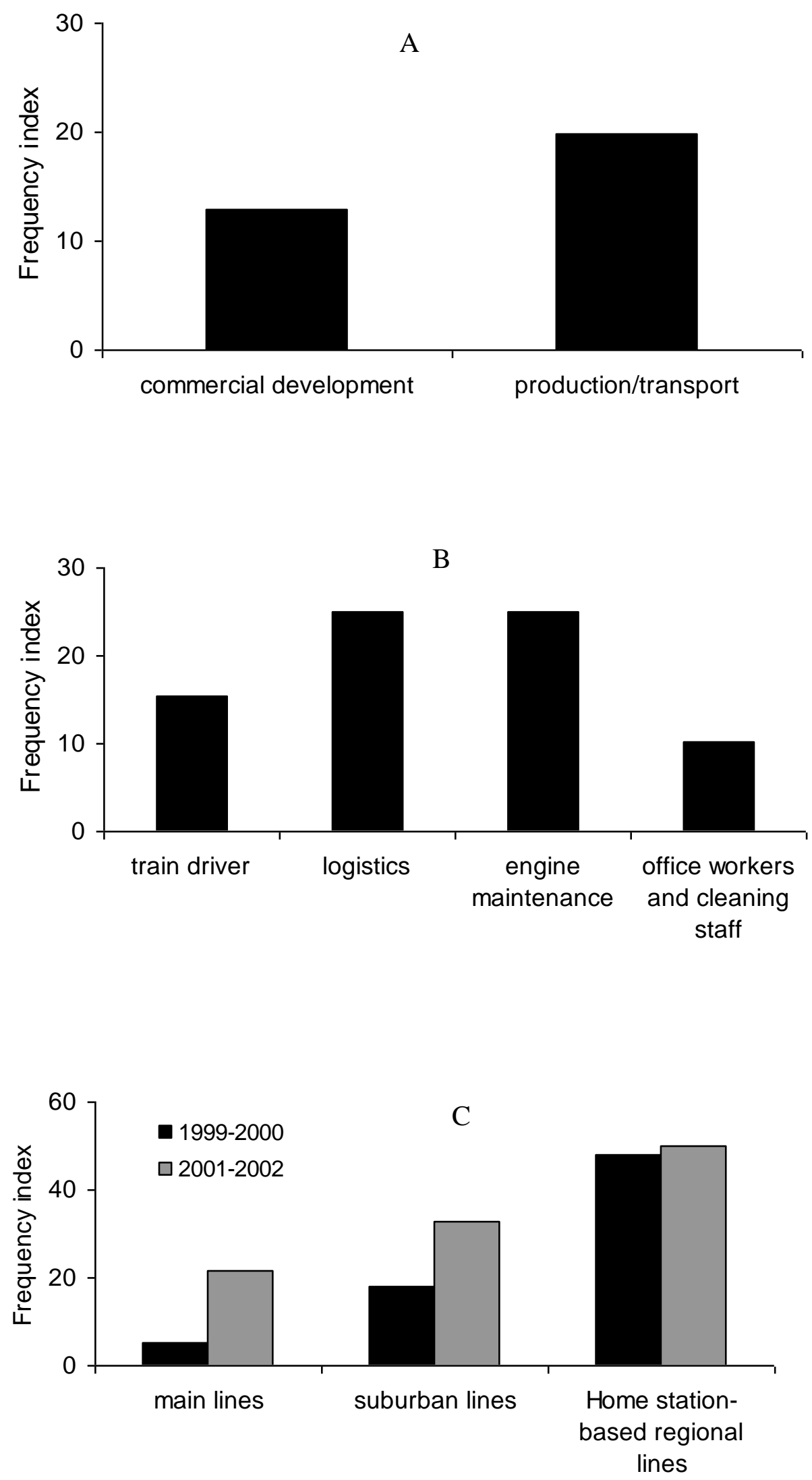

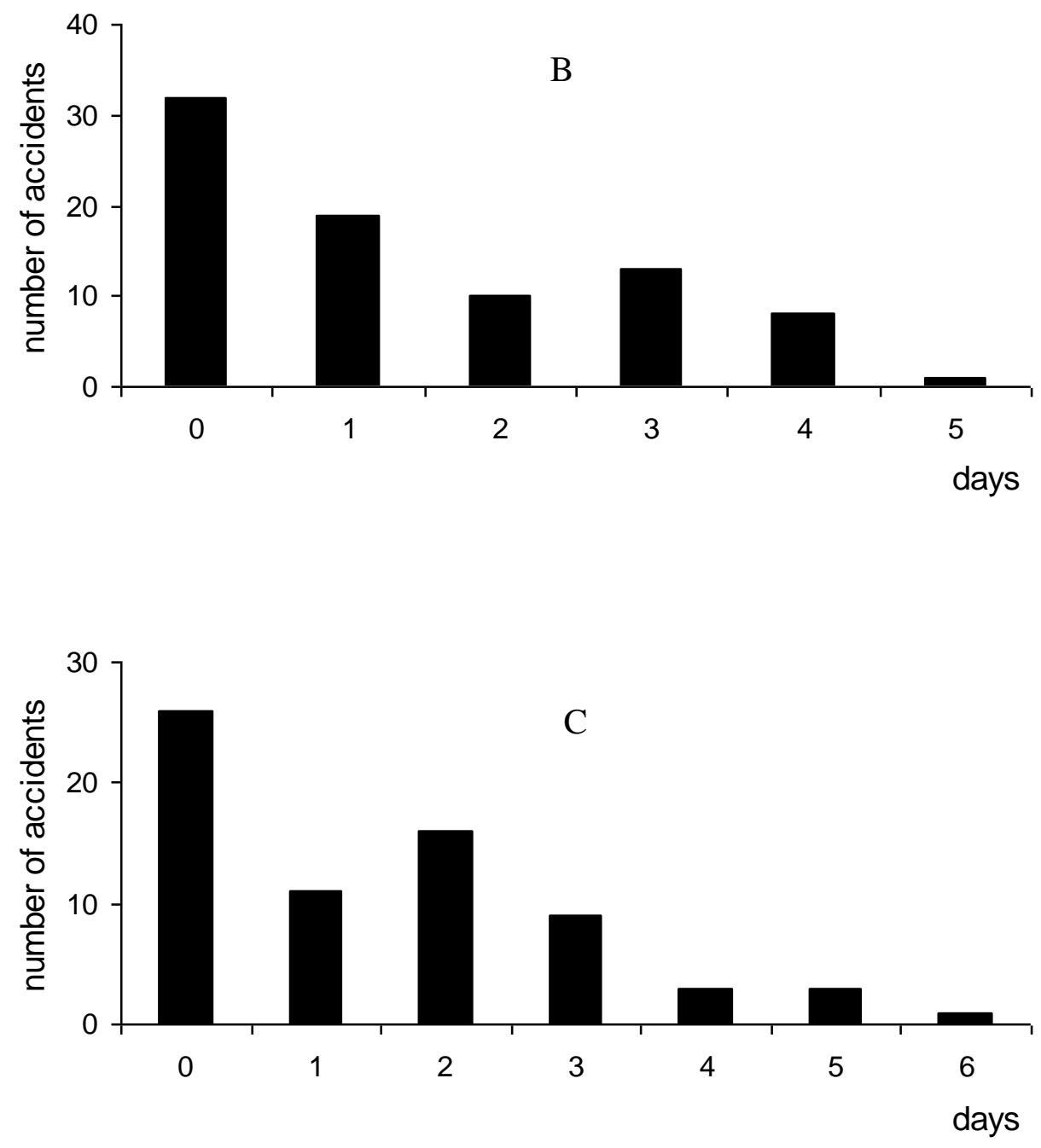


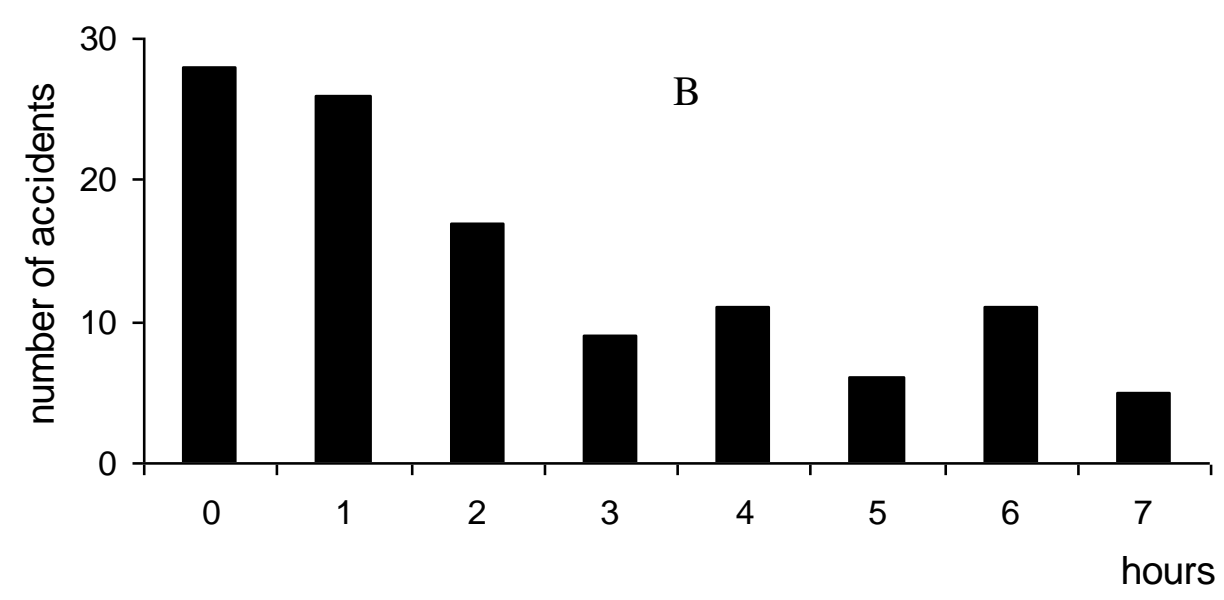




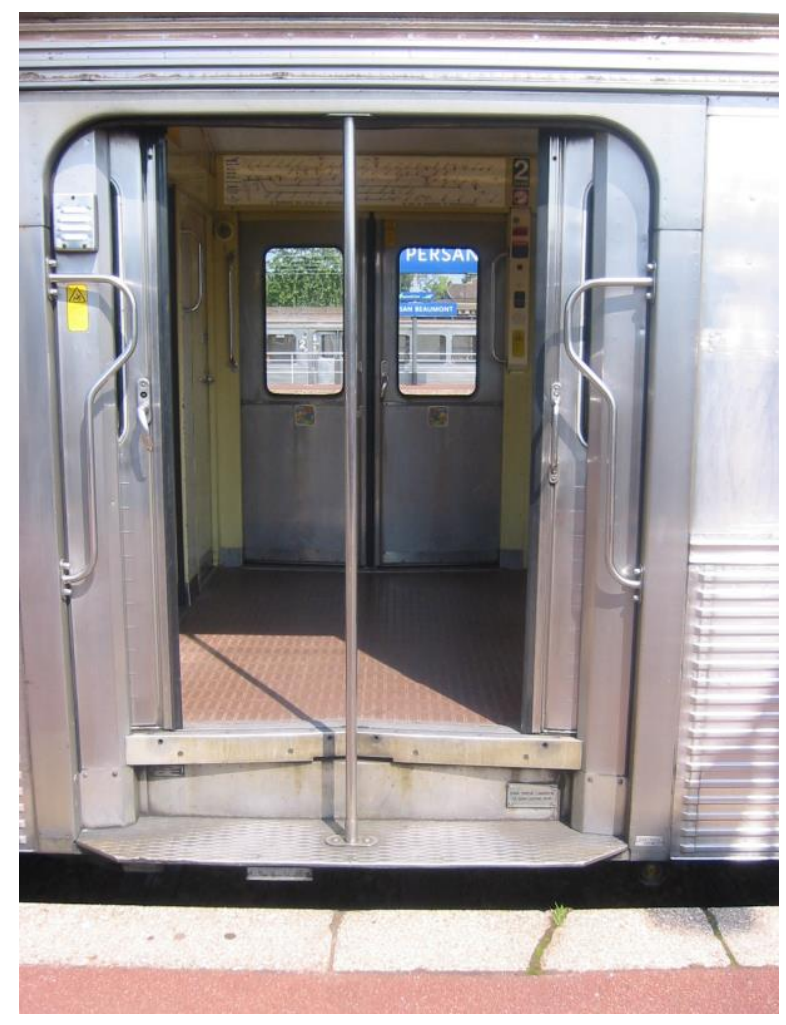

